\title{
IDENTIFICATION OF THE FACTORS AFFECTING CUSTOMER ENGAGEMENT IN ONLINE BRAND COMMUNITIES: A PILOT STUDY
}

\author{
Pelin Bayraktar and Sevgi Özkan Yıldırım \\ Middle East Technical University, Dumlupınar Bulvarı No:106800 Ankara/Turkey
}

\begin{abstract}
Social commerce is defined as a new wave of e-commerce in which traditional e-commerce is mediated by social media and social networking services in order to promote online transactions and shopping-related information exchanges. One of the main application of social commerce is 'online brand communities'. Although utilization of social media in order to advance customer brand engagement has proliferated significantly in recent years, most of the companies have not met the expected level of engagement of their customers yet. Overall, the key factors that could explain customer engagement are not yet thoroughly identified. Therefore, the current study develops a conceptual customer engagement model that aims to explain customer engagement in online brand communities. Customer engagement in brand social media is related to interactions and communications with the brand and other customers. In this study, the antecedents and outcomes of customer engagement dimensions will be investigated. As different dimensions of engagement can be influenced by factors from different aspects, it is important to cover as many categories as possible. Therefore, the model includes various factor categories including social, brand related, self-oriented and contend related factors drawn from relevant literature. The research instrument was designed, and a pilot study was conducted with 75 participants to assure content validity and to test reliability. This paper contributes to understanding the factors influencing each dimension of customer engagement to brand communities.
\end{abstract}

\section{KEYWORDS}

Customer Engagement, Brand Communities, Engagement Dimensions, Brand Loyalty

\section{INTRODUCTION}

The emergence of social media has changed the way of the communication between customers and companies. Relations based on one-way information flow have given their place to more participatory and interactive communication. This structure has strengthened the customer's position in the communication and gave them a more active role in influencing the company 


\section{IDENTIFICATION OF THE FACTORS AFFECTING CUSTOMER ENGAGEMENT IN ONLINE}

BRAND COMMUNITIES: A PILOT STUDY

and enhancing company performance (Brodie et al., 2011). Social media is an effective tool that allows companies understand their customers and their expectations, communicate with their customers, present their identity, products or services, and receive feedback from their customers in order to enhance their performance (Guesalaga, 2016). Therefore, companies should invest time and money to social networks in order to establish engagement with customers (de Castro, 2017). Customers can gain value from social media in various forms. They can gather useful and up-to-date information, socialize by interacting with like-minded customers, present their self-identity to the community, directly communicate their expectations and suggestions to the company, and gain economic benefits such as coupons or deals.

Consumer engagement has become a popular research area after it was specified as a key research priority for future research. Brodie et al. (2011) defined consumer engagement as a psychological state that occurs through customer experiences and having cognitive, emotional, and behavioral dimensions. However, there is a lack of consensus on its definition, conceptual domain and dimensionality. Customer engagement is ahead of similar concepts of participation and involvement by requiring an active interactive relationship with the engaged object (Marbach et al., 2016).

Brand community is defined as "a specialized, non-geographically bound community, based on a structured set of social relationships among admirers of a brand" (Muniz and O'guinn, 2001). With the emergence of online technologies, online brand communities have been started to serve as an additional channel for the organizations to communicate with their customers and receive their feedback (Chan et al., 2014). The relationships in online brand communities can be between the customer and the brand, the customer and the customer or the customer and the product (Jahn and Kunz, 2012). Although customer engagement can occur in brand generated platforms such as brand social media channels or brand pages, a great deal of engagement takes place on consumer generated platforms governed by individuals such as Facebook groups (Schamari and Schaefers, 2015).

Customer engagement includes various behaviors such as reading content, watching brand related videos, commenting on a content, sharing a content with others, rating products and companies, and creating and posting user generated content (Barger et al., 2016; Men and Tsai, 2015). Muntinga et al. (2011) classified those behaviors in different engagement levels and proposed a consumers' online brand related activities (COBRAs) topology. This topology clustered behaviors between consumers and brands under consumption, contribution and creation levels representing a gradual involvement with brand-related content. As the first level, consuming refers to the weakest activeness level where the customers act as passive observers of the social network sites and communities. As the second level, contributing is one level up and includes communication with brands and others by giving their contributions like sharing and commenting. Finally, creating is the strongest level including co-creation and content production activities (de Castro, 2017).

In the literature, several studies aimed to find the significant factors affecting customer engagement in brand communities (Jayasingh and Venkatesh, 2016; Carlson et al., 2017; Guo et al., 2017). They focused on various factor types including social factors such as tie strength, trust, social identity, trust and reciprocity (Chahal and Rani, 2017; Kang et al., 2016; Carlson et al. 2017; Tsai and Men, 2017; Tha'er and Bohari, 2016), content based factors such as perceived usefulness and perceived enjoyment (Guo et al., 2017; Carlson et al, 2017; Dessart et al., 2015; Chahal and Rani, 2017), brand related factors such as satisfaction and brand image (Dessart et al., 2015; Carlson et al., 2017) and customer related factors such as self image enhancement and altruism (Simon et al., 2016; Jahn and Kunz, 2012; Luarn et al., 2016; Marbach et al., 2016). 
IADIS International Journal on WWW/Internet

Some of the studies focused on specific engagement behaviors. Huang et al. (2013) focused on information seeking, knowledge creating and interaction sharing behaviors. Cvijikj and Michahelles (2013) examined the impact of post characteristics on brand page engagement behaviors of liking, commenting, and sharing content. Kabadayi and Price (2014) revealed that personality traits positively influence liking and commenting behaviors. Tha'er and Bohari (2016) examined user engagement in brand SNSs focusing on knowledge contribution behavior. Luarn et al. (2016) found that personal and social factors positively influence engaging in WOM behavior on social network sites.

Another group of studies approach customer engagement from a multi-dimensional point of view. Heinonen (2017) focused on the effect of customer based factors on behavioral, emotional and cognitive dimensions of customer engagement. Kuzgun and Josiassen (2016) investigated the relationship between different engagement dimensions and revealed the effect of cognitive dimension on emotional dimension and emotional dimension on behavioral dimension.

In order to provide strategic guidelines to companies for increasing customer engagement and developing communication strategies, it is important to determine the factors that the customers value most for interacting with the brand and other community members. Customer engagement in brand social media is related to interactions and communications with the brand and other customers, it can be affected by various factor categories such as social factors, brand factors, customer factors, etc. As different levels of engagement can be influenced by factors from different aspects, it is important to cover as many categories as possible. Although customer engagement is defined as a multi-dimensional concept including cognitive, emotional and behavioral dimensions, there is no comprehensive study investigating which factor influences which engagement dimension. Although the relationship between engagement dimensions has been investigated in a small number of studies, the mediating effect of these dimensions between the factors and other dimensions has not been examined yet. Loyalty has emerged as a consequence of customer engagement in a various studies, but the relationship between loyalty dimensions and engagement dimensions has not been investigated. The purpose of this study is to identify the factors that affect cognitive, emotional and behavioral engagement of customers in brand related social media. Also, relationships between customer engagement dimensions and loyalty dimensions will be investigated.

\section{CONCEPTUAL MODEL}

The aim of this research is to determine the factors influencing the cognitive, emotional and behavioral dimensions of customer engagement in online brand communities. Therefore, proposed model should include the factors representing social, brand related, self-oriented and content based factors in order to gain a wider perspective and increase explanation power of the model. The conceptual model, Customer Engagement Evaluation Model (CEEM) in Online Brand Communities, is given in Figure 1. 


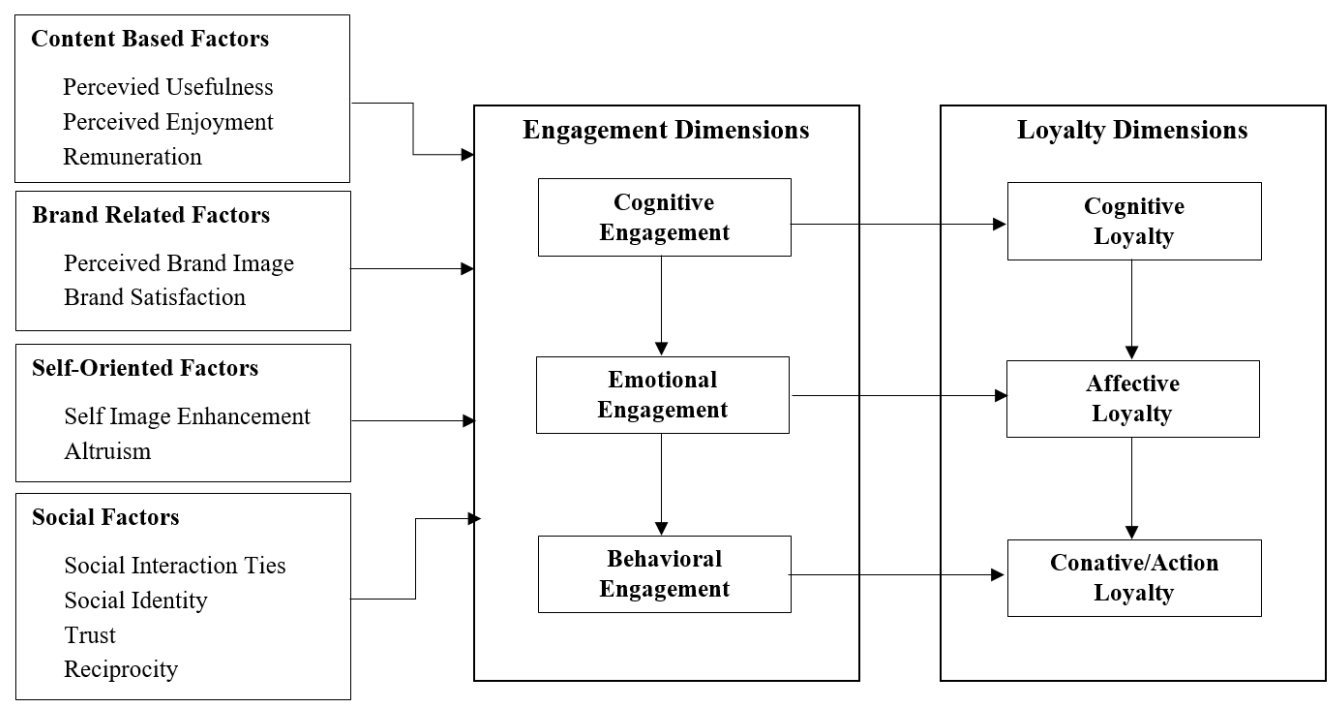

Figure 1. The proposed Customer Engagement Evaluation Model (CEEM) in online brand communities

\subsection{Customer Engagement}

In terms of dimensionality, the literature offers both unidimensional and multi-dimensional definitions of customer engagement. Some studies adopted a unidimensional approach to the concept and focused extensively on the behavioral aspects of engagement (Brodie et al., 2011). However, several authors suggested that customer engagement includes cognitive, emotional and behavioral dimensions (Brodie et al., 2011). Patterson et al. (2006) defined three key dimensions of customer engagement as vigor, dedication, absorption and interaction. Also Hollebeek and Chen (2014) defined dimensions as cognitive processing, affection and activation. Although many other studies used different concepts to represent the dimensionality, those dimensions correspond to the generic cognitive, emotional and behavioral nature of engagement.

Cognitive engagement represents the processing, concentration and interest in an object (de Castro, 2017) and refers to being immersed in the content of the brand social platform. Emotional engagement is expected to occur through recurrent feeling of these emotional responses after a certain time of satisfying cognitive immersion in brand social networks (Kuzgun and Josiassen, 2016) and refers to the consumer's level of excitement, interest, pleasure and happiness derived from engaging in brand related content and interactions with brand community and its members. Behavioral engagement refers to the willingness to devote time and effort to the brand social platform. This level of engagement is considered as the strongest engagement level. Kuzgun and Josiassen (2016) found that cognitive engagement has a direct effect on emotional engagement and emotional engagement has a direct effect on behavioral engagement in virtual brand communities. 


\subsection{Antecedents of Customer Engagement}

Various social factors have been proposed as drivers of customer engagement (Simon et al., 2016; de Castro, 2017; Luarn et al., 2016; Carlson et al., 2017; Chahal and Rani, 2017; Huang et al., 2013). Also, Jahn and Kunz (2012) suggested that one most prominent needs of customers is related to content-oriented area which is based on functional and hedonic values. As one of the main objects of customer engagement is brands, factors such as the perception of the customers about the brand and perception that the brand meet their expectations will affect the level of engagement. Jahn and Kunz (2012) stated that customer engagement is driven by particular needs of individuals such as achieving status or need for diversion. Therefore, we include social, content based, brand related and self-oriented factors in our model as antecedents of customer engagement.

\subsubsection{Social Interaction Ties}

With its interactive nature, social media supports two way communication between customers and brands as well as between customers and customers. More and more brands are using social media channels as a way to communicate more effectively with their customers, to increase brand visibility and awareness, and to increase customer engagement in order to manage customer relationships. The relationship in a brand related social media includes interaction with brand and interaction with other users. Social interaction ties refer to the intensity of interaction and closeness of relationships between community members in a social network. Chang and Chuang (2011) stated that the strong connections and direct ties between community members increase the intensity and sustainability of knowledge exchange in virtual communities.

Chahal and Rani (2017) depicted that tie strength strongly influence customer engagement in brand social media. Luarn et al. (2016) found that tie strength have a positive influence on user engagement in WOM on social networks. Jahn and Kunz (2012) revealed that both social interaction value and brand interaction value affect fan page engagement.

\subsubsection{Trust}

Since social media are interactive communication channels, the users not only follow what the brand is saying, but also join in conversation with the brands and other community members. The communication in virtual communities exists between a customer and other unfamiliar community members or the brand. Community trust refers to relying on the honesty, reliability and trustworthiness of other community members (Kang et al., 2016) and it is a crucial factor for interactions in brand-related social media (Kang et al., 2016; Lu et al., 2010).

Trust has been offered as an antecedent of customer engagement in various studies (Chahal and Rani, 2017; Youssef et al., 2018; Van Doorn et al., 2010). Kucukemiroglu and Kara (2015) indicated that trust positively affects opinion seeking behavior in Facebook brand communities. Chu and Kim (2011) confirmed the effect of community trust on customer eWOM behavior. Tamjidyamcholo et al. (2013) found that trust significantly affects knowledge sharing intention in online virtual communities. Similarly Chiu et al. (2006) revealed the effect of trust in knowledge sharing in virtual communities. Also some studies examined and demonstrated the moderating role of brand community trust on brand social media engagement (Chahal and Rani, 2017; Kang et al., 2016). 


\subsubsection{Social Identification}

Identification refers to customers' sense of emotional belongingness and shared representation of themselves with a social group (Simon et al., 2016). Customers who feel sense of belongingness to a brand community and feel them as important and valuable part of the community tend to engage in community activities and maintain committed relationships with the community (Chiu et al., 2006). Also, customers identify more with the brands matching their self-image and view them as a part of themselves and use social media to present their self-image by expressing their belongingness to the community (Simon et al., 2016). Identification with the brand and the community deepens community engagement by enhancing group oriented attitudes and motivation to exchange knowledge and also deepen customer brand relationships (Men and Tsai, 2013; Simon et al., 2016).

Prior studies on customer engagement revealed social identity to be significant predictor of brand social media engagement (Chahal and Rani, 2017; Men and Tsai, 2013; Men and Tsai, 2015); Simon et al., 2016). Huang et al. (2013) investigated the effect of social identification on engagement dimensions (consuming, contributing and creating) and found that identification significantly impacts all types of virtual engagements. Tsai and Men (2017) performed cross-cultural investigation of the antecedents of customer engagement in brand pages and found that community identification is a positive predictor of engagement. Chiu et al. (2006) revealed that the effect of identification to knowledge sharing behavior is positive and significant.

\subsubsection{Reciprocity}

Adams (1965, p.278) defined reciprocity as "the equality of exchange between parties" (Schaufeli et al., 1996). Community members expect reciprocity to balance their investments and gains from the community (Mathwick et al., 2007). Their expected future returns could be exchanged in-kind or alternate form of aid (Schaufeli et al., 1996). Previous studies indicated that norm of reciprocity is a significant driver of information exchange and knowledge sharing behaviors in online environments (Kankanhalli et al., 2005; Wasko and Faraj, 2005). Tha'er and Bohari (2016) found reciprocity as the most influential factor affecting engagement in knowledge contribution in virtual networks. Similarly, Chiu et al. (2006) showed that reciprocity increased quantity of knowledge sharing in virtual communities.

\subsubsection{Perceived Usefulness}

Perceived usefulness is defined as "the extent to which an individual believes that using an information system will enhance their productivity" (Davis, 1989). In social media context, Hussein and Hassan (2017) refers perceived usefulness as the extent to which the users believe that social media meets their various needs such as socialization, being informed and enjoyment of using social media. However, most of the studies differentiate useful and entertaining content (Guo et al., 2017; Reitz, 2012) and considered perceived usefulness as rational evaluations of customers on being able to access useful, helpful, accurate, relevant, and up-to-date of content (Carlson et al., 2017; Guo et al., 2017). When the customers perceived high information quality, they perceive social media as beneficiary and efficient tool to obtain updated information and suggestions. Accessing quality content promotes customers to follow brand social media more closely and feel involved (Guo et al., 2017). It will not be possible to ensure the sustainability of continued use and engagement in brand social media activities unless the customer perceive the usefulness of brand social media. 
IADIS International Journal on WWW/Internet

Chahal and Rani (2017) found that information availability as a customer based factor influences customer engagement to social media. De Castro (2017) proposed that information which refers to the desire of people to enhance their knowledge as a driver of customer engagement with online brand communities and information is proved to be a driver of passive engagement behavior. Cheung and To (2016) revealed the effect of perceived usefulness on attitude toward co-creation in social media. Reitz (2012) hypothesized that perceived information quality positively influence all of cognitive, affective and participative customer engagement dimensions. Their results showed that customers who perceive information quality in brand Facebook page are likely to be cognitively engaged.

\subsubsection{Perceived Enjoyment}

Perceived enjoyment is defined as "an intrinsic motivation that emphasizes the usage process and reflects the pleasure and enjoyment associated with the using a system" (Praveena and Thomas, 2014, p.25). Calder and Malthouse (2005) stated that customers engage in online activities regarding not only utility or quality of the content but also hedonic or emotional factors such as interestingness and enjoyment of the content. While the quality of social media content is a very important factor, customers may lose their interest if the content is not enjoyable (Reitz, 2012). Enjoyment is found to increase participation, excitement and concentration of customers to online activities (Schmidt and Spreng, 1996). Many users are entering social media for entertainment or relaxing purposes (de Castro, 2017). In social media context, Chiang (2013) found that a similar concept perceived playfulness, which defines perceived fun and enjoyment of social media activities, significantly influence continued use of social media. Online communities utilized for not only exchanging knowledge but also socialization purposes with other members; therefore, perceived enjoyment can be said to include both interestingness/enjoyment of the content and pleasure of engaging in brand related interaction on social networks in engagement context (Yesiloglu, 2018).

Gretzel and Yoo (2008) found that enjoyment motivations positively influence engaging with eWOM. Various studies demonstrated the effect of enjoyment on customer engagement in brand related social media (Guo et al., 2017; Chahal and Rani, 2017; Tsai and Men, 2017; Chen and Lin, 2014). Yesiloglu (2018) examined the effect of enjoyment on consuming and contributing engagement types and showed the positive influence of enjoyment on consuming and contributing brand/product related posts on social media. (Reitz, 2012) investigated the effect of entertainment on cognitive, affective and participation dimensions. Similarly, Huang et al. (2017) performed similar study on vigor, dedication and absorption dimensions. Both studies revealed that perceived enjoyment positively predicted all engagement dimensions.

\subsubsection{Remuneration}

Economic incentives have been considered as extrinsic motivator and related to monetary benefits called remuneration (Hussain at al., 2018). Remuneration refers to expectations of customers in gaining rewards and economic incentives (Yesiloglu, 2018). Companies suggest large amounts stimuli including rewards, promotions, discounts, and coupons to increase the motivation of their customers to encourage participation and engagement in their social media (Guo et al., 2017). Earlier studies concluded that economic benefits drive customers to maintain relationships with the brand, to read online reviews (Hussain at al., 2018), to share information (Lee and Bradlow, 2011), to participate eWOM , to join brand communities and to engage in brand related social networks (Guo et al., 2017; Muntinga et al., 2011; Yesiloglu, 2018). Wirtz et al. (2013) found that monetary incentives increase short term participation intentions for both 
active and passive members, but the motivations of active members decrease when the incentives expire. Chan et al. (2014) stated that the customers will feel obliged to devote themselves and the level of engagement will increase when they perceive rewards from the brand community. de Castro (2017) showed that economic incentives positively affect passive behavior and it is the strongest driver of posting behavior. Dessart et al. (2015) indicated that benefits from participating in brand community including explicit monetary incentives enhance affect, cognition and behaviors of the community members.

\subsubsection{Perceived Brand Image}

Brand image refers to the beliefs and subjective perceptions of a customer about a particular brand (Nandan, 2005). Customers combine impressions about the brand that they received from various sources to form a perceived brand personality. Park et al. (1986, p. 135) defined brand image as "the understanding consumers derive from the total set of brand related activities engaged by the firm". Brand personality and brand image are the two concepts that have been used interchangeably to measure perceptions of customers about the brands. Davies et al. (2004) proposed a brand personality scale including agreeableness, enterprise, competence, chic, and ruthless dimensions.

Mousavi et al. (2017) stated that customers' perceptions of brand prestige and brand distinctiveness influence brand identification. When a brand has a strong image, it will increase the attractiveness of the brand and willingness of customers to associate with the brand to gain social prestige. Brand image is mostly defined by brand prestige and brand distinctiveness that satisfies symbolic needs such as self-enhancement and psychological needs of customers such as uniqueness; respectively (He et al., 2012). Chahal and Rani (2017) revealed that brand image is a significant predictor of brand equity. He et al. (2012) indicated the effect of brand image on satisfaction, trust, value and loyalty. Mousavi et al. (2017) showed that brand prestige and brand distinctiveness affect brand commitment and positive word of mouth behavior indirectly through self-categorization.

\subsubsection{Brand Satisfaction}

Tse and Wilton (1988, p. 204) defined brand satisfaction as "the consumer's response to the evaluation of the perceived discrepancy between prior expectations (or some other norm of performance) and the actual performance of the product as perceived after its consumption", and it is a key factor for the stability of customer-brand relationships (Ling and Pedersen, 2006). Satisfaction arises when customers perceive that the benefits provided by the company exceed the expectations of customers (Carlson et al., 2017). Satisfaction is viewed as a determinant of various purchase-related and beyond purchase customer behaviors (Kumar, Dalla Pozza, \& Ganesh, 2013; Youssef et al., 2018). Also, it is considered as a key factor affecting customer engagement behaviors (Van Doorn et al., 2010). Carlson et al. (2017) stated that when the customers derive benefits from their relationships with brands, they tend to reciprocate by developing brand engagement intentions. Dessart et al. (2015) revealed that online brand community engagement is driven by brand knowledge, satisfaction and trust. Zhu et al. (2016) demonstrated the positive influence of satisfaction on providing feedback, recommending and helping behaviors of customers. Carlson et al. (2017) found that customer satisfaction significantly affects feedback and influencer behavior intentions. When the customers are satisfied with the brand and its products or services will be likely to engaged in brand related social media. 


\subsubsection{Self-Image Enhancement}

By providing customers an area for self-presentation, brand social media enables customer's self-image enhancement. Social enhancement is defined as the perceived value of being recognized or approved by other members of the social network on account of one's contributions to and relationships with the brand (Dholakia et al., 2004). Besides social and economic benefits, gaining recognition and reputation of other community members and the focal brand is a strong motivation to customers for community participation (Simon et al., 2016; Nambisan and Baron, 2010). By engaging in community activities, customer can present their self-concept, create perception about themselves, and gain recognition and reputation from others. Simon et al. (2016) found that self-image enhancement value of brand pages positively influences brand community engagement and concluded that customers view brand pages as valuable stages for self-presentation and forming positive impressions and use this stage through their engagement. Also they revealed that self-image enhancement drives customer brand identification. Similarly, Jahn and Kunz (2012) showed that high self-concept value leads to higher fan page engagement.

\subsubsection{Altruism}

Altruism is defined as "the intention to benefit others as an expression of internal values, regardless of social or motivational reinforcement" (Price et al., 1995, p. 257). It refers to concerning for others without expecting compensation (Luarn et al., 2016). Through social networks, customers can reach a large number of people and share their brand related knowledge and experiences to help them in reaching the necessary information or in making purchasing decisions. Consumers tend to help not only other community members but also the company by sharing their experiences and ideas that improve the brand and its products or services to reciprocate a satisfying customer experience with the brand (Yesiloglu, 2018). Yesiloglu (2018) differs altruism from helping the company and stated that altruism is focused to other community members as the object and helping the company is focused to the brand as the object. Helping motivation enhances customer engagement behavior such as sharing knowledge or brand generated content with others that they concern, writing reviews or creating brand related posts or eWOM (Luarn et al., 2016; Hennig-Thurau et al,, 2003). Marbach et al. (2016) proposed that altruism is positively related to cognitive, emotional and behavioral dimension of engagement.

\subsection{Consequences of Customer Engagement}

Prior studies have repeatedly demonstrated that engagement is associated with a number of positive outcomes, such as organizational commitment (Wirtz et al., 2013; Jahn and Kunz, 2012), customer loyalty (Wirtz et al., 2013; Jahn and Kunz, 2012; Marbach et al., 2016), membership continuance intentions (Wirtz et al., 2013), and purchase intentions (Chan et al., 2014; Jahn and Kunz, 2012; Jayasingh and Venkatesh, 2016).

Brand loyalty is defined as "a deeply held commitment to rebuy or repatronize a preferred product or service consistently in the future" (Oliver, 1997, p. 392). Oliver (1997) specified dimensions of loyalty as cognitive, affective, conative and active loyalty. Cognitive loyalty is based on the beliefs of customers that the brand is preferable to its alternatives. Those beliefs may result from prior knowledge of or experiences with the brand. After these cumulative satisfying experiences, positive attitude toward the firm has developed which brings the 
customer into affective loyalty phase. Affective loyalty reflects deeper level of commitment than cognitive loyalty. Conative loyalty refers to intention of repurchase influenced by repeated positive affect toward the brand. Various studies on engagement propose loyalty as a consequence of customer engagement (Dessart et al., 2015; de Castro, 2017; Harrigan et al., 2017).

\subsection{Instrument Development and Pilot Study}

To develop the instrument, the conceptual definitions of each construct of the model were defined. To measure the constructs in the model, an item pool was generated using the established measures from prior literature and minor modifications were made to the items to fit them to the context of customer engagement.

Content validity is defined as "the degree to which items in an instrument reflect the content universe to which the instrument will be generalized" (Straub et al., 2004, p. 424). In order to ensure content validity, expert review procedure was conducted with three experts from scale development domain. They evaluated the survey items according to their conformance of the related construct definition. Also they assisted in making corrections on the wording and semantic structure of the questionnaire. The final survey items have been selected from the item pool considering their representativeness of the construct's conceptual definition. As a result, the item pool including 63 items was formed.

After the review, the items were translated into Turkish. The back-translation procedure proposed by Brislin (1986) was followed for the translation of the items from English into Turkish. At first, a bilingual native speaker of the source language and a bilingual native speaker of target language translated the scale items from English to Turkish. Afterwards, they collaboratively review the translations and finalize the Turkish version. And then, the items in Turkish were translated again into English by another bilingual speaker. This version was compared with the original version of the survey items and the accuracy of the target translation was ensured. After the formation of the questionnaire, cognitive interviews were conducted with two potential subjects to assess the understandability of the questions and to get feedback and suggestions about the questionnaire. According to the feedback and suggestions of the participants, some of the items those are not clear were revised.

Then, in order to test the instrument in terms of reliability and construct validity, a pilot study was conducted. The brief of questions of the instrument including one sample for each construct is given in Table 1 . 
IADIS International Journal on WWW/Internet

Table 1. Brief of questions of the survey instrument

\begin{tabular}{|c|c|c|}
\hline Construct & Sample Question & Reference \\
\hline Brand Satisfaction & Brand $[\mathrm{X}]$ has lived up to my expectations. & Solem (2015) \\
\hline Brand Image & Brand $[\mathrm{X}]$ is reliable. & Chahal and Rani (2017) \\
\hline Trust & $\begin{array}{l}\text { I feel safe in my postings with the }[\mathrm{X}] \text { brand } \\
\text { community. }\end{array}$ & Chahal and Rani (2017) \\
\hline Altruism & $\begin{array}{l}\text { I feel good when I can help answer other community } \\
\text { members' questions. }\end{array}$ & Casas et al. (2016) \\
\hline Reciprocity & $\begin{array}{l}\text { I believe that members in the }[\mathrm{X}] \text { brand community } \\
\text { would help me if I need. }\end{array}$ & Chiu et al. (2006) \\
\hline Perceived Enjoyment & The content of the $[\mathrm{X}]$ brand community is exciting. & Carlson et al. (2017) \\
\hline Perceived Usefulness & $\begin{array}{l}\text { The content of the }[\mathrm{X}] \text { brand community is useful for } \\
\text { me. }\end{array}$ & Jahn et al. (2012) \\
\hline Remuneration & $\begin{array}{l}\text { I follow }[\mathrm{X}] \text { brand community because of incentives } \\
\text { I receive. }\end{array}$ & Guo et al. (2017) \\
\hline Self-Image Enhancement & $\begin{array}{l}\text { I follow }[\mathrm{X}] \text { brand community because I can present } \\
\text { others who I am. }\end{array}$ & Jahn et al. (2012) \\
\hline Social Interaction Ties & $\begin{array}{l}\text { I know some members in the }[\mathrm{X}] \text { brand community } \\
\text { on a personal level. }\end{array}$ & Chiu et al. (2006) \\
\hline Social Identity & $\begin{array}{l}\text { The }[\mathrm{X}] \text { brand community's identity is reflection of } \\
\text { my self-image. }\end{array}$ & Chahal and Rani (2017) \\
\hline Cognitive Engagement & $\begin{array}{l}\text { Time flies when I am interacting with the }[\mathrm{X}] \text { brand } \\
\text { community. }\end{array}$ & Huang et al. (2013) \\
\hline Emotional Engagement & $\begin{array}{l}\text { I pay a lot of attention to anything about the }[\mathrm{X}] \text { brand } \\
\text { community. }\end{array}$ & Huang et al. (2013) \\
\hline Behavioral Engagement & I devote lots of energy to the $[\mathrm{X}]$ brand community. & Huang et al. (2013) \\
\hline Cognitive Loyalty & Overall quality of brand $[\mathrm{X}]$ is the best. & Yuksel et al. (2010) \\
\hline Affective Loyalty & I like brand $[\mathrm{X}]$ more than other brand. & Yuksel et al. (2010) \\
\hline Conative Loyalty & I consider brand $[\mathrm{X}]$ to be my first choice. & Yuksel et al. (2010) \\
\hline
\end{tabular}

\subsubsection{Demographics of the Participants}

The questionnaire reached 141 participants but only 75 of them stated that they follow a brand community (53.2\%). $57 \%$ of the respondents are female and $43 \%$ are male. Most of the participants (\%73.3) were between 20-39 years-old. Over $89 \%$ of the respondents had bachelors or upper degrees. $76 \%$ of the respondents were employed and $12 \%$ of them were students. $40 \%$ of the respondents use social media between 30 minutes and 1 hour a day and $\% 33.3$ use it 1 to 3 hours a day. $26.7 \%$ of the respondents spend more than 3 hours a day using social media. The most widely used social media platform is Instagram. $90 \%$ of the respondents use the brand community for consuming type behaviors such as reading product reviews or product ratings and viewing the dialogues of other customers, $37 \%$ of them use it for contributing type behaviors such as rating products or brands, commenting on brand related content and media and only $20 \%$ of them use it for creating type behaviors such as publishing brand related content or making recommendations. $75 \%$ of the participants that perform contributing or creating type behaviors in their brand community are also found to be engaged in the brand community. $67 \%$ of the participants that use social media more than 1 hour a day and $89 \%$ of the participants in unemployed or retired occupation status are engaged in the brand community that they join. 


\subsubsection{Reliability Analysis}

Since the pilot study was conducted in smaller scale, not all the reliability and validity measures would be applicable. Reliability analysis was performed using IBM SPSS Statistics v25. The Cronbach's Alpha values were examined. In terms of reliability analysis, Cronbach's alpha loadings would be above .70 (Hair, 1998) and all the constructs of our model fulfill the condition. Total reliability was found as 0.974 . The Cronbach's Alpha values for each construct (ranged between 0.724 and 0.967 ) are given in Table 2.

Table 2. Cronbach's Alpha values of constructs

\begin{tabular}{llll}
\hline Construct & $\begin{array}{l}\text { Cronbach's } \\
\text { Alpha }\end{array}$ & Construct & $\begin{array}{l}\text { Cronbach's } \\
\text { Alpha }\end{array}$ \\
\hline Brand Satisfaction & 0.967 & Social Interaction Ties & 0.936 \\
Perceived Brand Image & 0.914 & Social Identity & 0.888 \\
Trust & 0.880 & Cognitive Engagement & 0.967 \\
Altruism & 0.963 & Emotional Engagement & 0.909 \\
Reciprocity & 0.724 & Behavioral Engagement & 0.941 \\
Perceived Enjoyment & 0.916 & Cognitive Loyalty & 0.881 \\
Perceived Usefulness & 0.949 & Affective Loyalty & 0.866 \\
Remuneration & 0.899 & Conative Loyalty & 0.890 \\
Self-Image Enhancement & 0.929 & &
\end{tabular}

Also, Cronbach Alpha if item deleted, item total correlation and inter item correlation values were analyzed. As a result, all the items were decided to be included into the questionnaire since all the constructs have Cronbach Alpha value greater than 0.7. Also, according to the Cronbach Alpha if item deleted values, there is no significant change in construct based Cronbach Alpha values when any item deleted from the questionnaire.

\section{CONCLUSION}

Given the brands' increasing use of social media for engaging their customers, there is a need to better understand the factors that affect customer engagement in brand related social platforms. Currently, consumer engagement has become a popular research area. Customer engagement with its multidimensional structure having cognitive, emotional and behavioral dimensions, is a complex process where various factors are expected to affect it. The aim of the study is to identify the factors that can influence the dimensions of customer engagement to brand related social platforms. Therefore, a model including various factors that represent different aspects of customer engagement is proposed: Customer Engagement Evaluation Model (CEEM) in Online Brand Communities. The model includes relationships between engagement dimensions, loyalty dimensions and also the relationships across engagement dimensions and their corresponding loyalty dimensions.

The factors were determined based on a systematic review of the established literature. The proposed model consists of social factors (social interaction ties, social identity, trust, reciprocity), content based factors (perceived usefulness, perceived enjoyment, remuneration), brand related factors (perceived brand image, brand satisfaction) and self-oriented factors 
IADIS International Journal on WWW/Internet

(self-image enhancement, altruism). Those constructs are considered as relevant influencers of each dimension of customer engagement in brand related social platforms. The proposed model (Customer Engagement Evaluation Model (CEEM) in Online Brand Communities) represents a starting point for understanding the antecedents and outcomes of each dimension of customer engagement. In this paper, empirical validity and reliability tests of the proposed model are presented. Future work will involve further validation of the model via various brand communities. For this purpose, a questionnaire is planned to be applied to the members of brand communities from automotive, technology and retail sectors.

\section{REFERENCES}

Barger, V. et al, 2016. Social media and consumer engagement: a review and research agenda. Journal of Research in Interactive Marketing, Vol. 10, No. 4, pp 268-287.

Brislin, R. W., 1986. Research instruments. Field methods in cross-cultural research, Vol. 8, pp 137-164.

Brodie, R. J. et al, 2011. Customer engagement: Conceptual domain, fundamental propositions, and implications for research. Journal of Service Research, Vol. 14, No. 3, pp 252-271.

Calder, B. J., and Malthouse, E. C., 2005. Managing media and advertising change with integrated marketing. Journal of Advertising Research, Vol. 45, No. 4, pp 356-361.

Carlson, J. et al, 2017. Go with the flow: engineering flow experiences for customer engagement value creation in branded social media environments. Journal of Brand Management, Vol. 24, No. 4 pp 334-348.

Časas, R. et al, 2016. The Links Between Social Motivational Engagements, Brand Community Commitment and Repurchase Intention Across Online Brand Communities. Organizations \& Markets in Emerging Economies, Vol. 7, No. 2.

Chahal, H., and Rani, A., 2017. How trust moderates social media engagement and brand equity. Journal of Research in Interactive Marketing, Vol. 11, No. 3, pp 312-335.

Chan, T. K. et al, 2014. Antecedents and consequences of customer engagement in online brand communities. Journal of Marketing Analytics, Vol. 2, No. 2, pp 81-97.

Chang, H. H., and Chuang, S. S., 2011. Social capital and individual motivations on knowledge sharing: Participant involvement as a moderator. Information \& management, Vol. 48, No. 1, pp 9-18.

Chen, E. Y. and Lin, Y. W., 2014. Mobile connection: An examination of antecedents to engage consumer in social network app. Proceedings of PICMET'14 Conference: Portland International Center for Management of Engineering and Technology; Infrastructure and Service Integration, pp 3184-3190.

Cheung, M. F. and To, W. M., 2016. Service co-creation in social media: An extension of the theory of planned behavior. Computers in Human Behavior, Vol. 65, pp 260-266.

Chiang, H. S., 2013. Continuous usage of social networking sites: The effect of innovation and gratification attributes. Online Information Review, Vol. 37, No. 6, pp 851-871.

Chiu, C. M. et al, 2006. Understanding knowledge sharing in virtual communities: An integration of social capital and social cognitive theories. Decision support systems, Vol. 42, No. 3, pp 1872-1888.

Chu, S. C., and Kim, Y., 2011. Determinants of consumer engagement in electronic word-of-mouth (eWOM) in social networking sites. International journal of Advertising, Vol. 30, No. 1, pp 47-75.

Cvijikj, I. P., and Michahelles, F., 2013. Online engagement factors on Facebook brand pages. Social Network Analysis and Mining, Vol. 3, No. 4, pp 843-861.

Davies, G. et al, 2004. A corporate character scale to assess employee and customer views of organization reputation. Corporate reputation review, Vol. 7, No. 2, pp 125-146. 


\section{IDENTIFICATION OF THE FACTORS AFFECTING CUSTOMER ENGAGEMENT IN ONLINE BRAND COMMUNITIES: A PILOT STUDY}

Davis, F. D., 1989. Perceived usefulness, perceived ease of use, and user acceptance of information technology. MIS quarterly, pp 319-340.

de Castro, A. P. R., 2017. Customer engagement in virtual social network brand communities: drivers and impact on brand loyalty (Master Dissertation, University of Porto).

Dessart, L. et al, 2015. Consumer engagement in online brand communities: a social media perspective. Journal of Product \& Brand Management, Vol. 24, No. 1, pp 28-42.

Dholakia, U. M. et al, 2004. A social influence model of consumer participation in network-and small-group-based virtual communities. International Journal of Research in Marketing, Vol. 21, No. 3, pp 241-263.

Gretzel, U. and Yoo, K. H., 2008. Use and impact of online travel reviews. Proceedings of the International Conference of Information and Communication Technologies in Tourism, Innsbruck, Austria, pp 35-46.

Guesalaga, R., 2016. The use of social media in sales: Individual and organizational antecedents, and the role of customer engagement in social media. Industrial Marketing Management, Vol. 54, pp 71-79.

Guo, L. et al, 2017. Transforming followers into fans: a study of Chinese users of the WeChat Official Account. Online Information Review, Vol. 41, No. 7, pp 1029-1045.

Hair, J.F., 1998. Multivariate Data Analysis, 5th Edition. Upper Saddle River, NJ: Prentice Hall.

Harrigan, P. et al, 2017. Customer engagement with tourism social media brands. Tourism Management, Vol. 59, pp. 597-609.

He, H. et al, 2012. Social identity perspective on brand loyalty. Journal of Business Research, Vol. 65 , No. 5, pp 648-657.

Heinonen, K., 2017. Positive and negative valence influencing consumer engagement. Journal of Service Theory and Practice.

Hennig-Thurau et al, 2003. Electronic word-of-mouth: Motives for and consequences of reading customer articulations on the Internet. International journal of electronic commerce, Vol. 8, No. 2, pp 51-74.

Hollebeek, D.L., and Chen, T., 2014. Exploring positively-versus negatively-valenced brand engagement: a conceptual model. Journal of Product \& Brand Management, Vol. 23, No. 1, pp 62-74

Huang, R. et al, 2013. Social capital in QQ China: Impacts on virtual engagement of information seeking, interaction sharing, knowledge creating, and purchasing intention. Journal of Marketing Management, Vol. 29, No. 3-4, pp 292-316.

Huang, T. et al, 2017. Why do players purchase in mobile social network games? An examination of customer engagement and of uses and gratifications theory. Program, Vol. 51, No. 3, pp 259-277.

Hussein, R., and Hassan, S., 2017. Customer engagement on social media: how to enhance continuation of use. Online Information Review, Vol. 41, No. 7, pp 1006-1028.

Hussain, S. et al, 2018. Consumers' online information adoption behavior: Motives and antecedents of electronic word of mouth communications. Computers in Human Behavior, Vol. 80, pp 22-32.

Jahn, B., and Kunz, W., 2012. How to transform consumers into fans of your brand. Journal of Service Management, Vol. 23, No. 3, pp 344-361.

Jayasingh, S., and Venkatesh, R., 2016. Determinants of Customer Brand Engagement in Social Media Sites: A Conceptual Framework. International Business Management, Vol. 10, No. 15, pp 2802-2807.

Kabadayi, S., and Price, K., 2014. Consumer-brand engagement on Facebook: liking and commenting behaviors. Journal of Research in Interactive Marketing, Vol. 8, No. 3, pp 203-223.

Kang, M. et al, 2016. The role of personalization, engagement, and trust in online communities. Information Technology \& People, Vol. 29, No. 3, pp 580-596.

Kankanhalli, A et al, 2005. Contributing knowledge to electronic knowledge repositories: an empirical investigation. MIS quarterly, Vol. 29, No. 1, pp 113-143. 
IADIS International Journal on WWW/Internet

Kucukemiroglu, S., and Kara, A., 2015. Online word-of-mouth communication on social networking sites: An empirical study of Facebook users. International journal of commerce and management, Vol. 25, No. 1, pp 2-20.

Kuzgun, E., and Josiassen, A., 2016. Brand Loyalty States as an Antecedent of Customer Engagement in Virtual Brand Communities, Proceedings of 11th Annual London Business Research Conference, London, UK, pp 104-121.

Lee, T. Y. and Bradlow, E. T., 2011. Automated marketing research using online customer reviews. Journal of Marketing Research, Vol. 48, No.5, pp 881-894.

Ling, R., and Pedersen, P. E., 2006. Mobile communications: Re-negotiation of the social sphere (Vol. 31). Springer Science \& Business Media.

Lu, Y.et al, 2010. From virtual community members to $\mathrm{C} 2 \mathrm{C}$ e-commerce buyers: Trust in virtual communities and its effect on consumers' purchase intention. Electronic Commerce Research and Applications, Vol. 9, No. 4, pp 346-360.

Luarn, P. et al, 2016. Motivations to engage in word-of-mouth behavior on social network sites. Information Development, Vol. 32, No. 4, pp 1253-1265.

Marbach, J. et al, 2016. Who are you and what do you value? Investigating the role of personality traits and customer-perceived value in online customer engagement. Journal of Marketing Management, Vol. 32 No. 5-6, pp 502-525.

Mathwick, C. et al, 2007. Social capital production in a virtual P3 community. Journal of consumer research, Vol. 34, No. 6, pp 832-849.

Men, L. R., and Tsai, W. H. S., 2013. Toward an integrated model of public engagement on corporate social networking sites: Antecedents, the process, and relational outcomes. International Journal of Strategic Communication, Vol. 7, No. 4, pp 257-273.

Men, L. R., and Tsai, W. H. S., 2015. Infusing social media with humanity: Corporate character, public engagement, and relational outcomes. Public Relations Review, Vol. 41, No. 3, pp 395-403.

Mousavi, S. et al, 2017. Interpreting social identity in online brand communities: Considering posters and lurkers. Psychology \& Marketing, Vol. 34, No. 4, pp 376-393.

Muniz, A. M., and O'guinn, T. C., 2001. Brand community. Journal of consumer research, Vol. 27, No. 4, pp 412-432.

Muntinga, D. G. et al, 2011. Introducing COBRAs: Exploring motivations for brand-related social media use. International Journal of advertising, Vol. 30, No. 1, pp 13-46.

Nambisan, S. and Baron, R. A., 2010. Different roles, different strokes: Organizing virtual customer environments to promote two types of customer contributions. Organization Science, Vol. 21, No. 2 , pp 554-572.

Nandan, S., 2005. An exploration of the brand identity-brand image linkage: A communications perspective. Journal of Brand Management, Vol. 12, No. 4, pp 264-278.

Oliver, R., 1997. Satisfaction: A Behavioral Perspective on the Consumer, McGraw-Hill, New York, NY.

Park, C. W. et al, 1986. Strategic brand concept-image management. The Journal of Marketing, Vol. 50, No. 4, pp 135-145.

Patterson et al, 2006. Understanding customer engagement in services. In advancing theory, maintaining relevance, proceedings of ANZMAC 2006 conference. Brisbane, pp. 4-6.

Praveena, K., and Thomas, S., 2014. Continuance intention to use Facebook: A study of perceived enjoyment and TAM. Bonfring International Journal of Industrial Engineering and Management Science, Vol. 4, No. 1, p 25.

Price, L. L. et al, 1995. Everyday market helping behavior. Journal of Public Policy \& Marketing, Vol. 14, No. 2, pp 255-266.

Reitz, A. R., 2012. Online consumer engagement: Understanding the antecedents and outcomes (Doctoral dissertation, Colorado State University). 


\section{IDENTIFICATION OF THE FACTORS AFFECTING CUSTOMER ENGAGEMENT IN ONLINE BRAND COMMUNITIES: A PILOT STUDY}

Schamari, J., and Schaefers, T., 2015. Leaving the home turf: How brands can use webcare on consumer-generated platforms to increase positive consumer engagement. Journal of Interactive Marketing, Vol. 30, pp 20-33.

Schaufeli, W. B. et al, 1996. Burnout and reciprocity: Towards a dual-level social exchange model. Work \& Stress, Vol. 10, No. 3, pp 225-237.

Schmidt, J. B. and Spreng, R. A., 1996. A proposed model of external consumer information search. Journal of the academy of Marketing Science, Vol. 24, No. 3, pp 246-256.

Simon, C. et al, 2016. The impact of external social and internal personal forces on consumers' brand community engagement on Facebook. Journal of Product \& Brand Management, Vol. 25, No. 5, pp 409-423.

Solem, B. A. A., 2015. The process of customer brand engagement in interactive contexts: Prerequisites, conceptual foundations, antecedents, and outcomes (Doctoral dissertation, Norwegian School of Economics and Business Administration).

Straub, D. et al, 2004. Validation guidelines for IS positivist research. Communications of the Association for Information systems, Vol. 13, No. 1, p 424.

Tamjidyamcholo, A. et al, 2013. Information security-Professional perceptions of knowledge-sharing intention under self-efficacy, trust, reciprocity, and shared-language. Computers \& Education, Vol. 68, pp 223-232.

Tha'er, A. M., and Bohari, A. M. B., 2016. Knowledge contribution determinants through social network sites: Social relational perspective. International Review of Management and Marketing, Vol. 6 , No. 3, pp 454-459.

Tsai, W. H. S., and Men, L. R., 2017. Consumer engagement with brands on social network sites: A cross-cultural comparison of China and the USA. Journal of Marketing Communications, Vol. 23, No.1, pp 2-21.

Tse, D. K., and Wilton, P. C., 1988. Models of consumer satisfaction formation: An extension. Journal of marketing research, Vol.25, No. 2, pp 204-212.

Van Doorn, J. et al, 2010. Customer engagement behavior: Theoretical foundations and research directions. Journal of service research, Vol. 13, No. 3, pp 253-266.

Wasko, M. M. and Faraj, S., 2005. Why should I share? Examining social capital and knowledge contribution in electronic networks of practice. MIS quarterly, Vol. 29, No. 1, pp 35-57.

Wirtz, J. et al, 2013. Managing brands and customer engagement in online brand communities. Journal of Service Management, Vol. 24, No. 3, pp 223-244.

Yesiloglu, S., 2018. To post or not to post: examining motivations of brand/product-related engagement types on social networking sites (Doctoral dissertation, Bournemouth University).

Youssef, Y. M. A. et al, 2018. A customer engagement framework for a B2B context. Journal of Business \& Industrial Marketing, Vol. 33, No. 1, pp 145-152.

Yuksel, A. et al, 2010. Destination attachment: Effects on customer satisfaction and cognitive, affective and conative loyalty. Tourism management, Vol. 31, No. 2, pp 274-284.

Zhu, D. et al, 2016. Effect of social support on customer satisfaction and citizenship behavior in online brand communities: The moderating role of support source. Journal of Retailing and Consumer Services, Vol. 31, pp 287-293. 